\title{
Advances in Agronomic Management of Indian Mustard (Brassica juncea (L.) Czernj. Cosson): An Overview
}

\author{
Kapila Shekhawat, S. S. Rathore, O. P. Premi, B. K. Kandpal, and J. S. Chauhan
}

Directorate of Rapeseed-Mustard Research, Sewar, Rajasthan Bharatpur 321 303, India

Correspondence should be addressed to Kapila Shekhawat, drrathorekapila@gmail.com

Received 15 November 2011; Revised 5 January 2012; Accepted 22 January 2012

Academic Editor: Sascha Rohn

Copyright ( $) 2012$ Kapila Shekhawat et al. This is an open access article distributed under the Creative Commons Attribution License, which permits unrestricted use, distribution, and reproduction in any medium, provided the original work is properly cited.

India is the fourth largest oilseed economy in the world. Among the seven edible oilseeds cultivated in India, rapeseed-mustard contributes $28.6 \%$ in the total oilseeds production and ranks second after groundnut sharing $27.8 \%$ in the India's oilseed economy. The mustard growing areas in India are experiencing the vast diversity in the agro climatic conditions and different species of rapeseed-mustard are grown in some or other part of the country. Under marginal resource situation, cultivation of rapeseedmustard becomes less remunerative to the farmers. This results in a big gap between requirement and production of mustard in India. Therefore site-specific nutrient management through soil-test recommendation based should be adopted to improve upon the existing yield levels obtained at farmers field. Effective management of natural resources, integrated approach to plant-water, nutrient and pest management and extension of rapeseed-mustard cultivation to newer areas under different cropping systems will play a key role in further increasing and stabilizing the productivity and production of rapeseed-mustard. The paper reviews the advances in proper land and seedbed preparation, optimum seed and sowing, planting technique, crop geometry, plant canopy, appropriate cropping system, integrated nutrient management and so forth to meet the ever growing demand of oil in the country and to realize the goal of production of 24 million tonnes of oilseed by $2020 \mathrm{AD}$ through these advanced management techniques.

\section{Introduction}

Rapeseed-mustard is the third important oilseed crop in the world after soybean (Glycine max) and palm (Elaeis guineensis Jacq.) oil. Among the seven edible oilseed cultivated in India, rapeseed-mustard (Brassica spp.) contributes $28.6 \%$ in the total production of oilseeds. In India, it is the second most important edible oilseed after groundnut sharing $27.8 \%$ in the India's oilseed economy. The share of oilseeds is $14.1 \%$ out of the total cropped area in India, rapeseed-mustard accounts for 3\% of it. The global production of rapeseed-mustard and its oil is around 3842 and $12-14 \mathrm{mt}$, respectively. India contributes $28.3 \%$ and $19.8 \%$ in world acreage and production. India produces around $6.7 \mathrm{mt}$ of rapeseed-mustard next to China (11-12 mt) and EU (10-13 mt) with significant contribution in world rapeseed-mustard industry. The rapeseed-mustard group broadly includes Indian mustard, yellow sarson, brown sarson, raya, and toria crops. Indian mustard (Brassica juncea (L.) Czernj. \& Cosson) is predominantly cultivated in
Rajasthan, UP, Haryana, Madhya Pradesh, and Gujarat. It is also grown under some nontraditional areas of South India including Karnataka, Tamil Nadu, and Andhra Pradesh. The crop can be raised well under both irrigated and rainfed conditions. Brown sarson (B. rapa ssp sarson) has 2 ecotypes lotni and toria. Yellow sarson (B. rapa var. trilocularis) is cultivated in Assam, Bihar, Orissa, and West Bengal as rabi crop. In Punjab, Haryana, UP, Himachal Pradesh, and Madhya Pradesh, it is grown mainly as a catch crop. Taramira (Eruca sativa) is grown in the drier parts of NorthWest India comprising the states of Rajasthan, Haryana, and UP. Gobhi sarson (B. napus L. ssp. oleferia DC. var annua L.) and karan rai (Brassica carinata) are the new emerging oilseed crops having limited area of cultivation. Gobhi sarson is a long duration crop confined to Haryana, Punjab, and Himachal Pradesh. It has good yield potential, wide adaptability and possesses high oil content of good quality. Karan rai yields well and shows better environment adoption and substantial resistance to pests and diseases. The country witnessed yellow revolution through a phenomenal 
TABLE 1: Salient features of cultivated species of rapeseed-mustard (Cruciferous) group of crops.

\begin{tabular}{lclrr}
\hline SN & Common name & Botanical name & Days to maturity (days) & Yield potential, Kg/ha \\
\hline$(1)$ & Indian mustard & Brassica juncea & $105-160$ & $1500-3000$ \\
$(2)$ & Yellow mustard & Brassica rapa var. yellow sarson & $120-155$ & $38-42$ \\
$(3)$ & Brown sarson & Brassica campestris & $100-235$ & $41-47$ \\
& & syn. B. rapa var. brown sarson & & $900-2000-45$ \\
$(4)$ & Black mustard & Brassica nigra & $70-90$ & $1000-1200$ \\
$(5)$ & Karan rai & Brassica carinata & $150-200$ & $40-41$ \\
$(6)$ & Toria & Brassica rapa var. toria & $70-100$ & $36-43$ \\
$(7)$ & Taramira & Eruca sativa & $140-150$ & $36-44$ \\
$(8)$ & Gobhi sarson & Brassica napus & $145-180$ & $34-38$ \\
\hline
\end{tabular}

increase in production and productivity from $2.68 \mathrm{MT}$ and $650 \mathrm{~kg} / \mathrm{ha}$ in $1985-86$ to $6.96 \mathrm{MT}$ and $1022 \mathrm{~kg} / \mathrm{ha}$ in $1996-$ 1997, respectively. In spite of these achievements, there exists a gap between production potential and actual realization. In India rapeseed-mustard is grown on an area of 5.53 Mha with production and productivity of $6.41 \mathrm{MT}$ and $1157 \mathrm{Kg} / \mathrm{ha}$, respectively [1].

Mustard is cultivated in mostly under temperate climates. It is also grown in certain tropical and subtropical regions as a cold weather crop. Indian mustard is reported to tolerate annual precipitation of 500 to $4200 \mathrm{~mm}$, annual temperature of 6 to $27^{\circ} \mathrm{C}$, and $\mathrm{pH}$ of 4.3 to 8.3 . Rapeseed-mustard follows $\mathrm{C}_{3}$ pathway for carbon assimilation. Therefore, it has efficient photosynthetic response at $15-20^{\circ} \mathrm{C}$ temperature. At this temperature the plant achieve maximum $\mathrm{CO}_{2}$ exchange range which declines thereafter. Rai is mostly grown as a rainfed crop, moderately tolerant to soil acidity, preferring a $\mathrm{pH}$ from 5.5 to 6.8 , thrives in areas with hot days and cool night and can fairly sustain drought. Mustard requires welldrained sandy loam soil. Rapeseed-mustard has a low water requirement (240-400 $\mathrm{mm}$ ) which fits well in the rainfed cropping systems. Nearly $20 \%$ area under these crops is rainfed. A review is prepared on advances on agronomic practices for enhancing the rapeseed-mustard production in India. A review of the work done on the different aspects in India and abroad especially under advance agronomic practices is done in this paper.

\section{Crop Adaptation and Distribution}

The rapeseed-mustard group includes brown sarson, raya, and toria crops. Indian mustard (Brassica juncea (L.) Czernj. \& Cosson) is predominantly cultivated in Rajasthan, UP, Haryana, Madhya Pradesh, and Gujarat. It is also grown under some nontraditional areas of South India including Karnataka, Tamil Nadu, and Andhra Pradesh. The crop can be raised well under both irrigated and rainfed conditions. Being more responsive to fertilizers, it gives better return under irrigated condition. Brown sarson (B. rapa ssp. sarson) has 2 ecotypes lotni and toria. Yellow sarson (B. rapa var. trilocularis) is cultivated in Assam, Bihar, Orissa, and West Bengal as rabi crop. In Punjab, Haryana, UP, Himachal Pradesh, and Madhya Pradesh, it is grown mainly as a catch crop. Taramira (Eruca sativa) is grown in the drier parts of North-West India comprising the states of Rajasthan, Haryana and UP. Gobhi sarson (B. napus l. ssp. oleferia DC. Var. annua L.) and karan rai (Brassica carinata) are the new emerging oilseed crops having limited area of cultivation. Gobhi sarson is a long duration crop confined to Haryana, Punjab, and Himachal Pradesh. It is photoand thermosensitive and makes little growth up to middle of February, but in the end of this month, plants make a quick growth. It has good yield potential, wide adaptability, and possesses high oil content of good quality. There are eight cultivated crops in rapeseed-mustard crop; the main characteristics features have been explained in Table 1.

Karan rai also yields well under a wide range of climate partly because it has a large number of primary and secondary racemes. It shows better environment adoption and substantial resistance to pests and diseases. Mustard is cultivated in most temperate climates. It is also grown in certain tropical and subtropical regions as a cold weather crop. Indian mustard is reported to tolerate annual precipitation of 500 to $4200 \mathrm{~mm}$, annual temperature of 6 to $27^{\circ} \mathrm{C}$, and $\mathrm{pH}$ of 4.3 to 8.3 . Rai is mostly grown as a rainfed crop, moderately tolerant to soil acidity, preferring a $\mathrm{pH}$ from 5.5 to 6.8 , thrives in areas with hot days and cool night, and fairly resistant to drought. Mustard requires good sandy loamy soil. The agroclimatic conditions of various locations under study have been explained in Table 2 .

\section{Varietals Development}

Since, there is a vast variability in the climatic and edaphic conditions in the mustard growing areas of India, the selection of appropriate cultivars is important as it helps in increasing the productivity. Introduction of relatively short duration cultivar found favor with the environment where effective growing seasonal length is short. Improved varieties of mustard stabilize oil and seed yield through insulation of cultivars against major biotic and abiotic stresses enhance oil (low erucic acid) and seed meal (low glucosinolate) quality. The first Indian mustard hybrid, named "NRCHB506," has been developed at Directorate of Rapeseed-Mustard Research, Bharatpur which can catapult the output of the country's key oil crop. The new hybrid is meant for cultivation in Rajasthan and Uttar Pradesh. Other high yielding varieties include "JM-1," "JM-3," and "Pusa Bold," 
TABLE 2: Agroclimatic conditions of various locations during mustard crop season.

\begin{tabular}{|c|c|c|c|c|c|c|c|c|c|c|c|}
\hline \multirow{2}{*}{ Location } & \multirow{2}{*}{ Longitude } & \multirow{2}{*}{ Latitude } & \multicolumn{2}{|c|}{ Temp, ${ }^{\circ} \mathrm{C}$} & \multirow[t]{2}{*}{ Rain fall, mm } & \multicolumn{2}{|c|}{$\mathrm{RH} \%$} & \multirow{2}{*}{ Soil texture } & \multicolumn{3}{|c|}{ Soil fertility, Kg/ha } \\
\hline & & & Max & Min & & Max & Min & & $\mathrm{N}$ & $\mathrm{P}$ & K \\
\hline Hisar & $75^{\circ} 43^{\prime} 6^{\prime \prime} \mathrm{E}$ & $29^{\circ} 9^{\prime} 11^{\prime \prime} \mathrm{N}$ & 3.2 & 34.2 & $50-200$ & 38 & 96 & Sany loam & 130 & 12 & 480 \\
\hline Pantnagar & $79^{\circ} 24^{\prime} 36^{\prime \prime} \mathrm{E}$ & $28^{\circ} 58^{\prime} 12^{\prime \prime} \mathrm{N}$, & 4.8 & 32.3 & $150-400$ & 47 & 92 & Clay loam & 155 & 15 & 310 \\
\hline Dholi & $85^{\circ} 35^{\prime} 22^{\prime \prime} \mathrm{E}$ & $26^{\circ} 0^{\prime} 2.2^{\prime \prime} \mathrm{N}$ & 6.6 & 33.3 & $200-550$ & 52 & 94 & Clay loam & 140 & 12.5 & 275 \\
\hline Ludhiana & $75^{\circ} 18^{\prime} \mathrm{E}$ & $30^{\circ} 34^{\prime} \mathrm{N}$ & 3.5 & 32.0 & $30-120$ & 45 & 95 & Loamy sand & 150 & 24 & 220 \\
\hline Bhubneshwar & $85^{\circ} 50^{\prime} \mathrm{E}$ & $20^{\circ} 16^{\prime} \mathrm{N}$ & 14.8 & 34.8 & $180-250$ & 38 & 94 & Clay loam & 130 & 19 & 175 \\
\hline
\end{tabular}

TABLE 3: Varieties tolerant to various abiotic and biotic stresses of mustard (Brassica juncea).

\begin{tabular}{lcl}
\hline SN & $\begin{array}{c}\text { Specific abiotic/biotic } \\
\text { stress }\end{array}$ & Tolerant verities \\
\hline (1) & Rainfed & $\begin{array}{l}\text { Aravali, Geeta, GM 1, PBR 97, PusaBahar, Pusa Bold, RH 781, RH 819, RGN 48, Shivani, TM } \\
\text { 2, TM 4, Vaibhav, RB 50 }\end{array}$ \\
$(2)$ & Salinity tolerant & CS 52, CS 54, Narendra Rai (NDR8501) \\
$(3)$ & Frost tolerant & RGN 13, RH 819, Swaranjyoti, RH 781, RGN 48 \\
$(4)$ & High temperature & Kanti, Pusa Agrani, RGN 13, Urvashi, NRCDR 02, Pusa mustard 25 (NPJ 112), Pusa mustard \\
tolerant & 27 (EJ 17) \\
(5) & White rust resistant & Basanti, JM 1, JM 2, NRCDR-2 \\
Alternaria blight & Jawahar Mustard 3, Him Sarson 1 (ONK 1), Ashirwad (RK-01-03) \\
\hline
\end{tabular}

“NRCDR-2," "NRCDR 601.” Their yield potentials vary from 16 to $25 \mathrm{q} / \mathrm{ha}$. At IARI, an early-maturing and bold seeded mustard variety has been developed called "Mehak" (B. juncea). This improved variety is suitable for early sowing to replace toria (B. rapa var. toria) in Delhi and adjoining areas. Gobhi sarson has a good yield potential, wide adaptability and possesses high oil content of good quality. "Hyola" (PAC401 ) is canola type hybrid rapeseed, developed in India by Advanta India Ltd, Holland-based multinational company. "Neelam" (HPN-3) and "Sheetal" (HPN-1) are the popular varieties of gobhi sarson [2]. Since inception of mustard research programme in India, number of tolerant varieties to various abiotic and biotic stresses of rapeseed-mustard has been developed (Table 3).

"Pusa Jaikisan" of B. juncea is the first variety though tissue culture. "TL-15," a toria variety has been recommended as summer crop for high altitude of Himachal Pradesh. In an attempt to incorporate resistance/tolerance to biotic and abiotic stresses in high yielding varieties, aphid tolerant strains like "RH-7846," "RH-7847," "RH-9020" and "RWAR-842," Alternaria blight moderately resistant variety "Saurabh"; white rust resistant variety, "Jawahar Mustard1"; salt tolerant varieties "Narendra Rai" and "CS-52" frost tolerant "RH-781" and "RH-7361" varieties have been identified. "RH-781" is also drought tolerant and suitable for intercropping. For nontraditional areas, Indian mustard varieties "Rajat," "Pusa Jaikisan" and "Sej.2" have been recommended.

\section{Land and Seedbed Preparation}

A mustard seedbed should be firm, moist, and uniform which allows good seed-to-soil contact, even planting depth and quick moisture absorption leading to a uniform germination. Tillage affects both crop growth and grain yield. The various tillage systems are as follows: conventional tillage includes moldboard ploughing followed by disc harrowing; reduced tillage includes disc ploughing followed by disc harrowing and complete zero tillage in which crop is sown under uncultivated soil. Minimum tillage, with or without straw, enhances soil moisture conservation and moisture availability during crop growth. As a consequence, the root mass, yield components and seed yield increase [3]. Zero tillage is preferred in mustard as it conserves more moisture in the soil profile during early growth period. Subsequent release of conserved soil moisture regulates proper plant water status, soil temperature, lower soil mechanical resistance, leading to better root growth and higher grain yield of mustard [4]. Success with minimum or zero tillage requires even distribution of crop residues, as a well-designed crop rotation and evenly distributing residue will create a firm, moist and uniform seedbed.

Continuous zero tillage results in redistribution of extractable soil nutrients with greater concentration near the soil surface, compared with conventional tillage where mixing of soil, residues, fertilizers, and lime results in a relatively homogeneous soil to the depth of tillage [6]. With zero tillage having greater root density in the surface soil but lesser root density below a depth of $15 \mathrm{~cm}$ in the soil profile. Therefore, $\mathrm{P}$ and $\mathrm{K}$ uptake by crops grown under zero tillage is greater than those grown by conventional methods. But the plant growth and dry matter yields of mustard under zero tillage will be higher only if $\mathrm{N}$ fertilizers are applied in appropriate amount [7]. Under AICRP on RM at Dholi, Kanke, Bhubaneshwar, and Behrampur maximum seed yield of toria and mustard was obtained in line sowing under zero 
TABLE 4: Seed yield (kg/ha) and oil content (\%) of toria as influenced by different $\mathrm{N}$ levels in utera cropping system at Bhubaneshwar.

\begin{tabular}{|c|c|c|c|}
\hline \multirow{2}{*}{ Cropping system } & \multicolumn{3}{|c|}{ N levels (kg/ha) } \\
\hline & 0 & 40 & 80 \\
\hline Rice: yellow sarson (broadcast) in utera cropping (at dough stage of rice) & $428(33.3)$ & $823(40.3)$ & $810(37.6)$ \\
\hline Rice: yellow sarson (broadcast) in utera cropping (sowing before harvest of rice) & $530(30.2)$ & $729(38.2)$ & $642(37.1)$ \\
\hline Rice: yellow sarson (line sowing) under zero tillage in rice field & $506(34.4)$ & $924(41.5)$ & $886(39.6)$ \\
\hline Rice: yellow sarson (line sowing) after land preparation in rice fields & $388(32.5)$ & $846(40.4)$ & $820(38.4)$ \\
\hline Rice: yellow sarson (broadcast) after land preparation in rice fields & $301(28.2)$ & $460(37.6)$ & $440(35.5)$ \\
\hline
\end{tabular}

CD at 5\% cropping system: 79 (0.7), $\mathrm{N}$ levels: 32 (0.4), Cropping system $\times \mathrm{N}$ levels: 98 (1.0). Figures in the parenthesis denotes oil content (\%).

Source: AICRP-RM, 2003 [5].

tillage practice which indicated that mustard can be grown well under zero tillage.

At Bhubaneshwar, line sowing of mustard under zero tillage after rice gave the maximum seed yield $(933 \mathrm{~kg} / \mathrm{ha})$ and oil content (38.4\%) (Table 4). The soil under zero tillage system contains higher amount of organic matter having more carbohydrate, amino acid and amino sugar that results in qualitative and quantitative improvement in soil and soil structure due to least soil disturbance. Energy output and input ratio are higher in zero tillage as compared to conventional tillage.

\section{Seed and Sowing}

Vigorous seedling growth, good root development, early stem elongation, rapid ground covering ability, and early flowering and radiation are important yield determining traits under low temperature and radiation regime. These traits can be successfully exploited in mustard if a good seed is grown at appropriate time along with maintaining an optimum plant population.

5.1. Seed Priming. Seed treatment is a useful practice for healthy plant growth. Seed priming through controlled hydration and dehydration enhances early germination of mustard seed in less time, even in compacted soil [8]. The soaking of mustard seeds in $0.025 \%$ aqueous pyridoxine hydrochloride solution for 4 hours improved germination. The combination of pyridoxine $+\mathrm{N}_{60} \mathrm{P}_{20}+\mathrm{N}_{15} \mathrm{P}_{5}$ (top dressing) accelerated the crop performance by enhancing seed yield and oil yield by 15.8 and $13.5 \%$, respectively, over the control [9]. The differential response of varieties for imbibition gives advantage to some of them to germinate early as compared to others. At Hisar, maximum rate of imbibition was reported in "NRCDR-2" (41.7\%) and minimum in "NRCDR-509" (7.5\%). Such drastic difference in rate of imbibition is important for identification of suitable varieties under abiotic stress conditions namely drought, frost, and temperature abnormalities.

5.2. Sowing Time. Sowing time is the most vital nonmonetary input to achieve target yields in mustard. Production efficiency of different genotypes greatly differs under different planting dates. Soil temperature and moisture influence the sowing time of rapeseed-mustard in various zones of the country. Sowing time influences phenological development of crop plants through temperature and heat unit. Sowing at optimum time gives higher yields due to suitable environment that prevails at all the growth stages. Though different varieties have a differential response to date of sowing, mustard sown on 14 and 21 October took significantly more days to $50 \%$ flowering (55 and 57) and maturity (154 and 156) compared to October 7 planting [10]. Delayed sowing resulted in poor growth, low yield, and oil content. The reduction in yield was maximum in " $\mathrm{RH}-30$ " and minimum in "Rajat" $[11,12]$.

Date of sowing influence the incidence of insect-pest and disease also. Sowing on October 21 resulted in least Sclerotinia incidence [13]. The maximum $\left(20.5-25.4^{\circ} \mathrm{C}\right)$ and minimum $\left(3.9-10.7^{\circ} \mathrm{C}\right)$ temperatures at the flowering stage of crops established through sowing on October 21 were negatively correlated with the development of Sclerotina stem rot. Mustard aphid (Lipaphis erysimi (Kaltenbach)) has been reported as one of the most devastating pests in realizing the potential productivity of Indian mustard. Normal sowing (1st week of November) also helps in reducing the risk of mustard aphid incidence.

5.3. Planting Technique. Sowing technique depends upon land resources, soil condition, and level of management and thus broadcast, line sowing, ridge and furrow method and broad bed and furrow method are common sowing techniques. At higher soil moisture regimes, broadcasting followed by light planking gives early emergence and growth. Under normal and conserved moisture regime, seed placement in moist horizon under line sowing becomes beneficial.

At Shillongani, broadcast method was found to be more successful. Significantly higher seed yield of toria (Brassica rapa var. toria) was harvested in broadcast sowing of toria over other practices. Toria broadcast at dough stage along with $80 \mathrm{~kg} \mathrm{~N} / \mathrm{ha}$ gave the highest yield (AICRP-RM, 2006). At Bhubaneshwar, line sowing of yellow sarson after land preparation produced maximum seed yield $(870 \mathrm{~kg} / \mathrm{ha})$ with $40 \mathrm{~kg} \mathrm{~N} / \mathrm{ha}$ [14]. At Behrampore, $40 \%$ higher seed yield of toria was obtained when sown in line after land preparation in the rice-based cropping system over broadcast (AICRP on RM, 2006). Paira or utera is a method of cropping in which the sowing of next crop is done in the standing previous crop without any tillage operation. Mustard sowing under paira/utera in the rice field has shown its edge over 


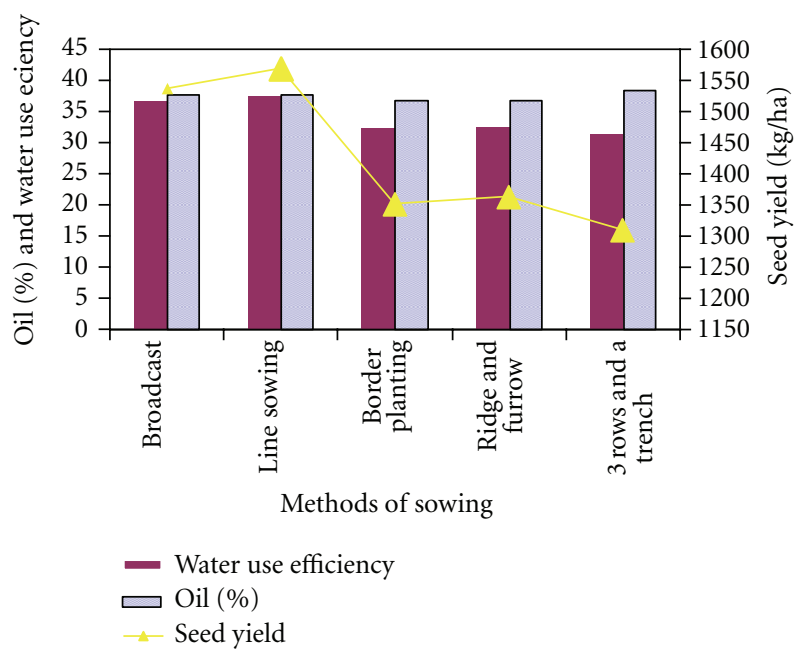

Figure 1: Seed yield, water use efficiency, Kg/ha-mm (WUE), and oil content of mustard (Brassica juncea) as influenced by various planting methods.

line sowing and broadcasting (Sowing of seeds by broad casting the seeds in the field) in eastern parts of India. At Dholi, mustard sown with paira cropping recorded significantly higher seed yield $(1212 \mathrm{~kg} / \mathrm{ha})$ over line sown and broadcast method, while these 2 methods yielded at par. At Bhubaneswar, significantly higher yield $(887 \mathrm{~kg} / \mathrm{ha})$ of mustard was recorded when sown as utera crop over line and broadcast sown crop [15].

Ridge and furrow sowing was superior to conventional flat sowing for growth parameters and yield of Brassica juncea [16]. Under saline condition, seed yield of canola in ridge sowing was higher by 45,31 , and $28 \%$ than broadcast, drill and furrow sowing methods, respectively [17]. The highest yield was associated with less saline environment at the ridges which allowed the seed to germinate and increase the yield. Transplanting of mustard has also been reported thereby saving time, and resources. Transplanting reduces days to maturity and results in higher seed yield. Ridge transplanting reduced water applied by $30 \%$ for each furrow as compared to $45 \mathrm{~cm}$ row spacing in flat method without any loss in seed yield. The corresponding increase in water use efficiency (WUE) was $27 \%$. In bed planting, there was a $35 \%$ saving in water resulting in $32 \%$ increase in WUE (Figure 1).

5.4. Crop Geometry. The competitive ability of a rapeseedmustard plant depends greatly upon the density of plants per unit area and soil fertility status. The optimum plant population density/unit area varies with the environment, the genotype, the seeding time, and the season. Uniform distribution of crop plants over an area results in efficient use of nutrients, moisture, and suppression of weeds leading to high yield. In wider row spacing, solar radiation falling within the rows gets wasted particularly during the early stages of crop growth whereas in closer row spacing upper part of the crop canopy may be well above the light saturation capacity but the lower leaves remain starved of light and contribute negatively towards yield.
Gobhi sarson (Brassica napus) being more vigourous, the days to maturity, plant height, branches, pod, seed weight per plant, seed index, seed yield, and oil content were higher at $60 \mathrm{~cm}$ row spacing [18]. An increase in rows up to $30 \mathrm{~cm}$ correspondingly prolonged maturity days followed by optimum $45 \mathrm{~cm}$ and wider rows $60 \mathrm{~cm}$ spacing. The plants receiving narrow row spacing increased vegetative growth. Due to shade and competition for nutrients and moisture the crop matures later by increasing developmental phases Taller plants were observed in the plots where crop was planted in rows of $60 \mathrm{~cm}$ apart followed by $45 \mathrm{~cm}$ and $30 \mathrm{~cm}$ row spacing due to sufficient space resulting in plants grown well and showed greater height [19] (Gupta, 1988). The regression coefficient indicated that each increase in row spacing up to $60 \mathrm{~cm}$ resulted in increased crop maturity by 0.54 days, plant height by $0.44 \mathrm{~cm}$, number of branches would increase by 0.11 , pods per plant by 1.96 , seeds per pod by 0.04 , seed weight per plant by 0.45 , seed index by $0.152 \mathrm{~g}$, oil content by $0.8 \%$ and increase in seed yield by $10.32 \mathrm{~kg} / \mathrm{ha}$. The recommended spacing for mustard is $30 \times 10$ and for hybrids it is $45 \times 10$. At Kumher, plant spacing $45 \times 15$ recorded significant higher seed yield over other spacing but was on a par with $45 \times 10 \mathrm{~cm}$. At Pantnagar, $30 \times 15$ recorded significantly higher seed yield which remained on a par with $45 \times 10$ and $45 \times 15 \mathrm{~cm}$ plant spacing [20].

5.5. Plant Population and Inter-Plant Shading. The dense plant population reduces the yield due to reduction in the photosynthetically active leaf area caused by mutual shading. In an experiment on Brassica juncea (Var. laxmi) the reduction is more due to shading at 91-110 DAS over 71-90 DAS. The specific leaf weight (SLW), crop growth rate (CGR), and net assimilation rate (NAR) were more adversely affected by $50 \%$ shading at $71-90$ DAS. Net assimilation ratio remained unaffected by $25 \%$ shading, while it reduced significantly by $50 \%$ shading at both the stages; the reduction was more with $50 \%$ due to shading at $91-110$ DAS. On an average $50 \%$ shading at $91-110$ DAS was more deleterious than $25 \%$ shading at $91-110$ DAS, that is, at terminal seed development stage (Table 5).

\section{Cropping System}

Physiography, soils, geological formation, climate, cropping pattern, and development of irrigation and mineral resources greatly influence selection of variety and cropping system. Fallow mustard is popular sequence in major mustard growing areas but studies show that some of the crop result in better resource utilization and high remuneration if included in mustard-based cropping system.

6.1. Mustard Productivity under Various Crop Sequences. Under AICRP trials at Dholi, fallow-mustard sequence gave significantly higher seed yield which was on a par with blackgram-mustard sequence: urdbean-mustard at Morena; greengram-mustard, guar-mustard, and pearlmillet-mustard at S. K. Nagar and Hisar; maize-mustard 
TABLE 5: Effect of shading on yield and growth parameters in Indian mustard at Hisar.

\begin{tabular}{lcccc}
\hline Treatment & Seed yield $(\mathrm{kg} / \mathrm{ha})$ & SLW $\left(\mathrm{mg} / \mathrm{cm}^{2}\right)$ & CGR $\left(\mathrm{g} / \mathrm{m}^{2} / \mathrm{day}\right)$ & $\mathrm{NAR}\left(\mathrm{mg} / \mathrm{m}^{2} / \mathrm{day}\right)$ \\
\hline Control & 571.6 & 8.3 & 7.3 & 10.8 \\
25\% shading at 71-90 DAS & 546.0 & 7.9 & 9.4 & 0.93 \\
25\% shading at 91-110 DAS & 490.9 & 6.4 & 9.9 & 0.87 \\
$50 \%$ shading at 71-90 DAS & 527.0 & 7.0 & 8.3 & 0.95 \\
$50 \%$ shading at 91-110 DAS & 380.0 & 1.3 & 1.0 & 0.83 \\
CD at 5\% & 33.1 & & 0.05 \\
\hline
\end{tabular}

Source: AICRP-RM, 2004.

TABLE 6: Seed yield (kg/ha), mustard equivalent yield (MEY), and gross return (Rs./ha) as influenced by various intercropping combinations under rainfed conditions at Hisar.

\begin{tabular}{|c|c|c|c|c|}
\hline Treatment & Main crop & Intercrop & MEY & Gross return (Rs./ha) \\
\hline Pure mustard & 2565 & - & 2565 & 29,497 \\
\hline Mustard + chickpea $(1: 5)$ & 966 & 1035 & 1956 & 22,494 \\
\hline Mustard + fieldpea $(1: 5)$ & 1002 & 189 & 1230 & 14,145 \\
\hline Mustard + linseed $(1: 5)$ & 996 & 642 & 1721 & 19,791 \\
\hline Mustard + lentil $(1: 5)$ & 1015 & - & 1015 & 11,672 \\
\hline Mustard without intercropping at same distance as in intercropping & 1097 & - & 1092 & 12,668 \\
\hline $\mathrm{CD}$ at $5 \%$ & - & - & 350 & - \\
\hline
\end{tabular}

Source: AICRP-RM, 1997 [11].

at Kangra and Pantnagar revealed superiority to fallowmustard. The productivity of the system also depends upon the fertility status and the nutrient supply. When mustard was grown after soybean or bajra, the response to $\mathrm{S}$ was observed up to $40 \mathrm{~kg} \mathrm{~S} / \mathrm{ha}$ [21]. Productivity measured in terms of land equivalent ratio (LER) was higher for intercropping of chickpea and mustard in the $4: 1$ row ratio than for sowing of chickpea and mustard in sole stands [22].

6.2. Inclusion of Gobhi Sarson (Brassica Napus) under Various Cropping Sequences. Gobhi sarson is comparatively recent introduction and hence needs identification of suitable cropping systems. Growing gobhi sarson and toria in alternate rows at $22.5 \mathrm{~cm}$ spacing is very remunerative. Maizegobhi sarson, blackgram-gobhi sarson, rice-gobhi sarson, and soybean-gobhi sarson were identified remunerative cropping systems at Kangra [21].

6.3. Mustard-(Brassica Juncea) Based Cropping System under Rainfed Areas. There are possibilities of increasing cropping intensity in monocropping mustard areas under rainfed condition. Green manuring or guar during rainy season enhance seed yield of succeeding mustard [12]. In addition to efficient resource use, intercropping imparts stability to productivity and reduces the risk of crop failure. Under irrigated conditions, at Bharatpur, the seed yield equivalent of mustard (Brassica juncea) was significantly higher where mustard was grown in combination with potato $(1: 3)$, mustard + wheat $(1: 5)$, mustard + barley $(1: 5)$ than pure mustard. At Hisar, intercropping Brassica juncea (variety RH-30) with rabi crops had revealed highest gross return (Rs. 29,498) when mustard was grown as a pure crop. The mustard seed equivalent was highest in mustard + chickpea
$(1: 5)$. Intercropping of mustard with chickpea, field pea, or linseed proved superior over their cultivation as a pure crop (Table 6).

\section{Fertilizer Management}

Adequate nutrient supply increases the seed and oil yields by improving the setting pattern of siliquae on branches, number of siliquae/plant, and other yield attributes [23]. Recommended dose of fertilizers (RDF) for different zones changes with climate, soil type, time, and type of cropping system followed.

7.1. Nitrogen and Phosphorus Fertilization. Nitrogen use efficiency is greatly influenced by the rate, source, and method of fertilizer application. The rate of nitrogen depends upon the initial soil status, climate, topography, cropping system in practice, and crop. Crop under zero tillage is also more productive $(695 \mathrm{~kg} / \mathrm{ha})$ with $80 \mathrm{~kg} \mathrm{~N} / \mathrm{ha}$ [14]. Increase in the nitrogen level up to $60 \mathrm{~kg} \mathrm{~N} /$ ha consistently and significantly increased the number of primary branches, number of seeds per siliquae and 1000 seed weight [24]; however, increasing the nitrogen level up to $90 \mathrm{~kg} / \mathrm{ha}$ increased the number of secondary branches per plant, number of siliquae per plant, and seed and straw yield with maximum cost benefit ratio of 3.03 [25]. Split application of total nitrogen in three equal doses one-each as basal, second after first irrigation and remaining one-third after second irrigation resulted in maximum increase in yield attributes and yield of Brassica juncea compared to application of total nitrogen in two split doses [26]. Top dressing of $\mathrm{N}$ fertilizers should be done immediately after first irrigation. Delaying of first irrigation, results in yield reduction of mustard crop. The application 
TABle 7: Effect of $\mathrm{N}$ and S levels (kg/ha) application on fatty acid composition and glucosinolate content in Brassica juncea cv. Varuna at Ludhiana.

\begin{tabular}{lccccccccc}
\hline $\mathrm{N}(\mathrm{Kg} / \mathrm{ha})$ & $\mathrm{S}(\mathrm{Kg} / \mathrm{ha})$ & $\begin{array}{c}\text { Glucosinolate content } \\
(\mu \text { moles/g in defatted } \\
\text { meal })\end{array}$ & $\begin{array}{c}\text { Palmitic } \\
\text { acid }\end{array}$ & $\begin{array}{c}\text { Stearic } \\
\text { acid }\end{array}$ & Oleic acid & $\begin{array}{c}\text { Linoleic } \\
\text { acid }\end{array}$ & $\begin{array}{c}\text { Linolenic } \\
\text { acid }\end{array}$ & $\begin{array}{c}\text { Eicosenoic } \\
\text { acid }\end{array}$ \\
\hline 75 & 0 & 64 & 2.61 & 1.17 & 11.78 & 14.99 & 6.48 & 50.91 & 11.80 \\
75 & 20 & 72 & 2.88 & 1.31 & 10.15 & 14.53 & 5.14 & 52.75 & 12.28 \\
100 & 0 & 52 & 2.58 & 1.58 & 13.16 & 15.31 & 7.01 & 49.55 & 10.57 \\
100 & 20 & 42 & 2.91 & 1.65 & 11.94 & 15.06 & 6.13 & 49.63 & 12.18 \\
125 & 0 & 52 & 3.01 & 1.33 & 12.19 & 16.17 & 5.91 & 47.71 & 12.26 \\
125 & 20 & 42 & 4.42 & 1.31 & 16.12 & 16.55 & 6.57 & 44.77 & 9.55 \\
\hline
\end{tabular}

Source: AICRP-RM, 2007 [14].

of nitrogen with presowing irrigation was superior to that of nitrogen application with last preparatory tillage. In case of nitrogen applied with pre-sowing irrigation single application of nitrogen was on a par with split application [27].

Application of phosphorus up to $60 \mathrm{~kg} / \mathrm{ha}$ significantly enhanced dry matter/plant. Plant height, branches per plant and leaf chlorophyll content increased with up to $40 \mathrm{~kg} \mathrm{P} / \mathrm{ha}$. The uptake of NPK and sulphur by both seed and stover increased significantly with successive increase in nitrogen levels up to $120 \mathrm{~kg} \mathrm{~N} / \mathrm{ha}$, sulphur levels up to $60 \mathrm{~kg} \mathrm{~S} / \mathrm{ha}$, and $\mathrm{P}_{2} \mathrm{O}_{5}$ level up to $60 \mathrm{~kg} \mathrm{P}_{2} \mathrm{O}_{5} /$ ha. Seed yield and yield attributes increased while oil content decreased with increasing level of nitrogen up to $120 \mathrm{~kg} / \mathrm{ha}$. Different levels of phosphorus increased seed yield, maximum being at $80 \mathrm{~kg}$ $\mathrm{P} /$ ha due to higher number of secondary branches/plant and consequently siliquae/plant. Oil content also increased with increase in levels of $\mathrm{N}, \mathrm{P}_{2} \mathrm{O}_{5}$, and $\mathrm{S}$. Activities of all nitrogen assimilating enzymes, namely; nitrate reductase, nitrite reductase, glutamine synthetase, and glutamate synthetase were found to be maximum at $100 \mathrm{~kg} \mathrm{~N} / \mathrm{ha}$.

7.2. Sulphur Fertilization. Among the oilseed crops, rapeseed-mustard has the highest requirement of sulphur [28]. Sulphur promotes oil synthesis. It is an important constituent of seed protein, amino acid, enzymes, glucosinolate and is needed for chlorophyll formation [29]. Sulphur increased the yield of mustard by 12 to $48 \%$ under irrigation, and by 17 to $124 \%$ under rainfed conditions [30]. In terms of agronomic efficiency, each kilogram of sulphur increases the yield of mustard by $7.7 \mathrm{~kg}$ [31].

Oil content in Canola-4 and Hyola-401 is 3\% higher than the hybrid "PGSH-51" due to the effect of various doses of nitrogen and sulphur, while the oleic acid content in these hybrids is double that "PGSH-51." "PGSH-51" had erucic acid ranging from 23.2 in to $29.4 \%$. At higher sulphur level there is $2-3 \%$ reduction in erucic acid content. However, lower level of nitrogen reduced erucic acid content by $3 \%$ with a concomitant increase in oleic acid (Table 7). Higher doses of sulphur along with low doses of nitrogen affect the chain elongation enzyme system thereby leading to reduction in erucic synthesis.

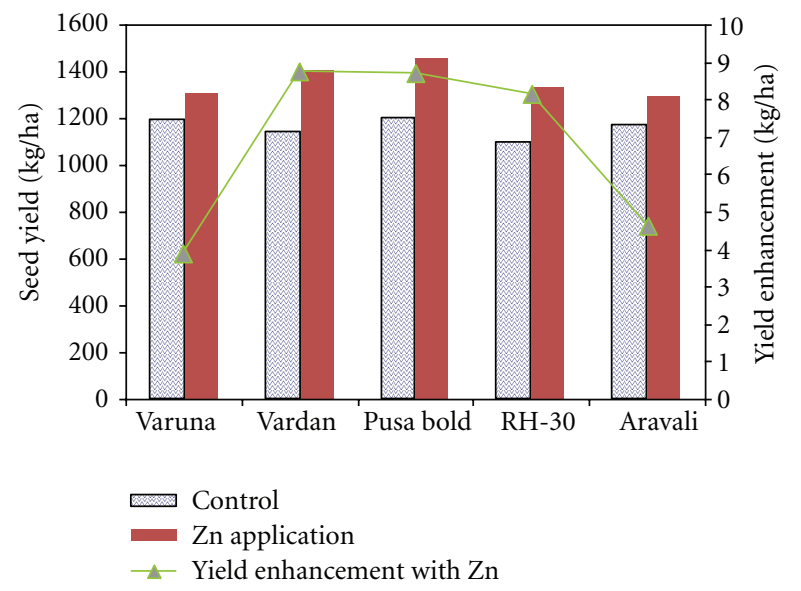

FIGURE 2: Influence of zinc application on seed yield of different cultivars of mustard.

A significant increase in yield was observed with increase in sulphur levels up to $40 \mathrm{~kg} \mathrm{~S} / \mathrm{ha}$ in mustard-based cropping system. At Bawal, the highest seed yield of mustard was recorded in green gram-mustard cropping sequence while the lowest $(2686 \mathrm{~kg} / \mathrm{ha})$ in pearl millet-mustard sequence. In rice-mustard sequence, the optimum seed yield of mustard was obtained at $40 \mathrm{~kg} \mathrm{~S} / \mathrm{ha}$ at Behrampore and for blackgram-mustard at Dholi. Each successive increase in S level increased seed yield up to $20 \mathrm{~kg} \mathrm{~S} / \mathrm{ha}$ at Dholi and Ludhiana, $40 \mathrm{~kg} \mathrm{~S} / \mathrm{ha}$ at S. K. Nagar, and $60 \mathrm{~kg} \mathrm{~S} / \mathrm{ha}$ at Behrampore and Morena conditions [32].

7.3. Micronutrients. Mustard, in general is very sensitive to micronutrient deficiency, specially zinc and boron. The increase in seed yield was $8.5 \%$ at $12.5 \mathrm{~kg} \mathrm{ZnSO}_{4} / \mathrm{ha}$. The harvest index (HI) was significantly affected by $\mathrm{Zn}$ application, although seed yield showed diminishing return with additional $\mathrm{ZnSO}_{4}$ doses (Table 8).

The response of various ideotype to the applied micronutrients varies considerably. The response of Indian mustard varieties, viz. 'Pusa Bold' and 'Vardan' to applied zinc was found higher (AICRP-RM, 2000) as compared to Varuna, RH- 30 and Aravali (Figure 2).

The concentration of $\mathrm{Zn}$ at flowering, pod formation stage, concentration and uptake of $\mathrm{Zn}$ in straw and grain 
TABLE 8: Effect of $\mathrm{Zn}$ on yield and yield attributes of indian mustard.

\begin{tabular}{|c|c|c|c|c|c|c|c|}
\hline $\begin{array}{l}\mathrm{ZnSO}_{4}(\mathrm{Kg} / \mathrm{ha}) \\
\text { levels }\end{array}$ & $\begin{array}{l}\text { Seed yield } \\
(\mathrm{kg} / \mathrm{ha})\end{array}$ & $\begin{array}{c}\text { Secondary } \\
\text { branches/plant }\end{array}$ & Oil content (\%) & Oil yield (kg/ha) & Protein (\%) & $\begin{array}{c}\text { Protein yield } \\
(\mathrm{kg} / \mathrm{ha})\end{array}$ & $\begin{array}{c}\text { Harvest index } \\
(\%)\end{array}$ \\
\hline 0 & 1161 & 6.5 & 40.2 & 465.6 & 22.1 & 255.2 & 21.6 \\
\hline 12.5 & 1260 & 8.1 & 39.9 & 501.1 & 22.5 & 281.9 & 22.4 \\
\hline 25.0 & 1336 & 9.6 & 39.9 & 532.4 & 22.6 & 301.6 & 22.9 \\
\hline 50 & 1414 & 12.4 & 39.9 & 570.0 & 22.5 & 318.6 & 22.2 \\
\hline $\mathrm{CD}$ at $5 \%$ & 33 & 0.7 & NS & 22.8 & NS & 18.8 & 0.8 \\
\hline
\end{tabular}

Source: AICRP-RM, 2000 [33].

at maturity and uptake of $\mathrm{Zn}$ in grain and straw at maturity of Indian mustard increased significantly with increase in Zn levels [34]. Similarly, the seed yield increased significantly $(16-47 \%)$ with the application of boron. The average response to boron application ranged from 21 to $31 \%$. The yield increase was due to $27 \%$ and $10 \%$ increase, respectively, in seeds/siliqua and 1000 seed weight, indicating the importance role in seed formation $[35,36]$.

7.4. Organic Sources of Nutrients. Bulky organic manures are applied to improve overall soil health and reduce evaporation losses of soil moisture. Depending upon the availability of raw material and land use conditions various organic sources, namely, clusterbean (green manure), Sesbania (green manure), mustard straw @ $3 \mathrm{t} / \mathrm{ha}$ and Vermicompost (2.5$7.5 \mathrm{t} / \mathrm{ha}$ ) have been evaluated at Bharatpur. Green manure with Sesbania gave significantly higher mustard seed yield at Bharatpur and Bawal. Sesbania green manuring has shown higher mustard yield and improved soil environment (AICRP-RM, 2006).

Many biostimulants also encourage higher production. At Hisar, foliar spray of Bioforce (an organic formulation) $2 \mathrm{~mL} / \mathrm{L}$ at the flowering and siliqua formation stage enhanced mustard seed yield (2059 kg/ha) [14].

7.5. Integrated Nutrient Management (INM). It is important to exploit the potential of organic manures, composts, crop residues, agricultural wastes, biofertilizers and their synergistic effect with chemical fertilizers for increasing balanced nutrient supply and their use efficiency for increasing productivity, sustainability of agriculture, and improving soil health and environmental safety. Balanced fertilization at right time by proper method increases nutrient use efficiency in mustard. Experiments have been conducted at different AICRP centres with the integrated use of organic manure, green manure, crop residue, and biofertilizers along with inorganic fertilizers. INM not only reduces the demand of inorganic fertilizers but also increases the efficiency of applied nutrients due to their favourable effect on physical, chemical and biological properties of soil. The introduction of leguminous crops in the rotational and intercropping sequence and use of bacterial and algal cultures play an important role in increasing the nutrient use efficiency [37].

7.5.1. Growth Promoter, BioFertiliser as a Component of INM. Biofertilizers are inoculants or preparation containing micro-organims that apply nutrients especially $\mathrm{N}$ and $\mathrm{P}$. Two types of $\mathrm{N}$-fixing microorganisms namely free living (Azotobacter) and associative symbiosis (Azospirillum) and two $\mathrm{P}$ supplying microorganisms, namely, phosphate solubilizing bacteria and vesicular arbuscular mycorrhiza (VAM) were extensively tested at various AICRP-RM centers. Inoculation of mustard seeds with efficient strains of Azotobacter and Azospirillum enhanced the seed yield up to 389 and $305 \mathrm{~kg}$ respectively with $40 \mathrm{Kg} \mathrm{N} / \mathrm{ha}$. The total NPK uptake was also higher with Azotobacter inoculation. The combined application of 10 t FYM + 90:45:45 NPK kg/ha with Azotobacter inoculation gave the highest $\mathrm{B}: \mathrm{C}$ ratio of 1.51 . At lower $\mathrm{N}$ levels, without inoculation, the seed yield decline was more as compared to inoculated treatment. Growth promoter's formulations like bioforce and biopower contain bio-amino acid, plant growth promoting terpenoid, siderophores, and attenuated bacteria fortified with BGA helped to increase water and nutrient absorption from the soil. Similarly, bioforce contains natural free amino acid, phytohormones, macro- and microelements and plant growth promoting terpenoid activated the cell division and stimulates plant growth, development, and photosynthate translocation. RDF $(80: 40: 0)$ along with $25 \mathrm{~kg}$ Biopower/ha + spray of Bioforce (11 in 500 litres of water) at 50\% flowering and pod filling stage gave significant higher yield of mustard over other combinations $[35,36]$.

7.5.2. Effect of INM on Quality of Mustard Oil. At Kanpur, INM studies were evaluated in maize-mustard, bajramustard, and fallow mustard sequence. In maize-mustard sequence, $100 / 75 \%$ of RDF + 2 t FYM gave highest seed yield and quality of the oil (Table 9 ).

7.5.3. Integrated Nutrient Management (INM) and Nutrient Use Efficiency. INM improves the nutrient uptake by mustard and hence enhances the use efficiency of various nutrients from the soil. The incorporation of $25 \%$ nitrogen through FYM $+75 \%$ by chemical fertilizer $+100 \%$ sulphur significantly enhanced the uptake use efficiency and of nitrogen and sulphur in both seed and stover of crop followed by $100 \% \mathrm{NS}$ and $50 \% \mathrm{~N}$ through FYM $+50 \%$ by chemical fertilizer $+100 \%$ S [38]. The highest mustardequivalent yield, which includes converted yield of other crops in to mustard seed yield based on market price of the crops (24.88 q/ha), net monetary returns (Rs. 15,537/ha), $\mathrm{B}: \mathrm{C}$ ratio (2.07), and agronomic efficiency (16.1) were 
TABLE 9: Effect of INM on quality of mustard (Kanti-RK 9807) under maize-mustard sequence.

\begin{tabular}{|c|c|c|c|c|c|c|c|c|}
\hline \multirow{3}{*}{ Treatment } & \multirow{3}{*}{ Legends } & \multirow{3}{*}{ Oil content $(\%)$} & \multicolumn{6}{|c|}{ Fatty Acid composition (\%) } \\
\hline & & & $16: 1$ & $18: 1$ & $18: 2$ & $18: 3$ & $20: 1$ & $22: 1$ \\
\hline & & & Palmtic acid & Oleic acid & Linoleic acid & Linolenic acid & Eicosenoic acid & Erucic acid \\
\hline RDF (120-40-40) & $\mathrm{T} 1$ & 40.4 & 2.8 & 18.4 & 10.1 & 10.6 & 4.3 & 52.7 \\
\hline $\mathrm{T}_{1}+10 \mathrm{t} \mathrm{FYM} / \mathrm{ha}$ & $\mathrm{T} 2$ & 40.9 & 2.8 & 16.3 & 13.3 & 10.4 & 4.1 & 52.2 \\
\hline $\mathrm{T}_{2}+40 \mathrm{Kg} \mathrm{S} / \mathrm{ha}$ & $\mathrm{T} 3$ & 40.4 & 2.9 & 18.0 & 14.4 & 12.2 & 3.2 & 48.6 \\
\hline $\mathrm{T}_{3}+\mathrm{Zn} \mathrm{SO} 425 \mathrm{~kg} / \mathrm{ha}$ & $\mathrm{T} 4$ & 40.3 & 2.8 & 17.8 & 14.9 & 10.1 & 6.1 & 47.3 \\
\hline $\mathrm{T}_{4}+\mathrm{B} 1 \mathrm{~kg} / \mathrm{ha}$ & T5 & 40.7 & 2.7 & 23.0 & 16.2 & 9.0 & 5.2 & 43.3 \\
\hline $\mathrm{T}_{1}+$ Crop residue (Maize) & T6 & 40.1 & 2.7 & 20.0 & 14.3 & 9.2 & 4.4 & 48.6 \\
\hline 75\% RDF & & 40.4 & 2.6 & 17.8 & 15.1 & 7.9 & 6.3 & 49.7 \\
\hline
\end{tabular}

Source: Modified from AICRP-RM, 2002 [21].

recorded with the application of $100 \%$ recommended $\mathrm{N}$ in the rainy season through FYM and $100 \%$ recommended NP in the winter season through inorganic fertilizers [39]. Agronomic efficiency is the response in terms of increase in mustard seed yield per unit use of nitrogen.

At Bharatpur and Jobner, 17.8 and $8.6 \%$ increase in seed yield was recorded with $50 \% \mathrm{RDF}+50 \% \mathrm{~N}$ through FYM and vermin-compost. Sole organic treated plot recorded 29.9\% lesser seed yield over RDF at Jobner [32]. Amount of available phosphorus increased over initial value when organic manures and crop residues were incorporated. Organic carbon status builds up in organic source incorporated plots. The application of $10 \mathrm{t} \mathrm{FYM} / \mathrm{ha}$ in addition to recommended dose of fertilizer (RDF) improved soil physical condition by improving aggregation, increased saturated hydraulic conductivity, and reducing bulk density and penetration resistance of the surface soil [40].

\section{Water Management}

Rapeseed-mustard crop is sensitive to water shortage. A substantial rapeseed-mustard area in Rajasthan (82.3\%), Gujrat (98\%), Haryana (75.6\%), and Punjab (92.4\%) is covered under irrigation. A positive effect of irrigating rapeseedmustard at critical stages is observed. Water use efficiency was highest when irrigation was applied at $0.8 \mathrm{IW}$ : CPE ratio and increased with increasing $\mathrm{N}$ rate $[41,42]$. Number of irrigations is important for working out the most efficient water use by mustard. For mustard, two irrigations, one at flowering stage and at siliqua formation stage increased seed yield by $28 \%$ over the rainfed plots [43]. Increase in the amount of water increased leaf water potential, stomatal conductance, light absorption, leaf area index, seed yield, and evapotranspiration and decreased canopy temperature [44]. In similar study by Panda et al. [45], an average increase in seed yield with irrigation at the flowering and pod development stages and irrigation at the flowering stage over the control was $62.9 \%$ and $41.7 \%$, respectively. However, for number of seeds per siliqua and oil content, single irrigation at 45 DAS remained parallel with two irrigations [46]. The water use efficiency was highest with one irrigation at 45 DAS. Crop receiving two irrigations at preflowering and pod-filling stages produce about 33 percent more seed than unirrigated crops [47]. Single irrigation given at vegetative stage is found to be most critical, as irrigation at this stage produces the highest yield. When two irrigations are given, the irrigation at vegetative and pod formation stages is of maximum benefit. The irrigation at vegetative, flowering, and pod formation stages resulted in the highest yield, where three irrigations were given. Oil and protein yield were also significantly affected by number and stages of irrigation (Table 10).

Irrigation is very important for getting the optimum productivity potential of mustard, but equally important is the quality of irrigation water. If the quality of irrigation water is poor, it needs certain treatment and management before being utilized for crop production. The increasing levels of salinity of the irrigation water applied at presowing and flower initiation reduces the plant height, the branching pattern, and the pod formation [48]. Irrigation with saline water $(12$ and $16 \mathrm{dS} / \mathrm{m})$ decreased the dry matter yield significantly when applied at pre-sowing or later. The saline irrigation at the pre-flowering stage or later reduced the grain yield by $50 \%$ and $70 \%$, respectively.

As a result of saline water irrigation, the soil water infiltration was reduced up to $7 \%$. The EC and exchangeable sodium percentage (ESP) were increased by $2.2 \mathrm{dSm}^{-1}$ and 9.0, respectively. The yield of mustard crop could be further increased by better leveling the plots, reducing the level difference to less than $10 \mathrm{~cm} \mathrm{[49].} \mathrm{The} \mathrm{ill} \mathrm{effects} \mathrm{of}$ saline water can be overcome with proper $\mathrm{N}$ management. Nonsaline water can be substituted by applying $\mathrm{N}$ and saline water [50].

\section{Weed Management}

Weeds cause alarming decline in crop production ranging from $15-30 \%$ to a total failure in rapeseed-mustard yield. The critical period is $15-40$ days. Weeds compete with crop plants for water, light, space, and nutrients. Therefore, timely and appropriate weed control greatly increases the crop yield and thus nutrient use efficiency. The common weeds of mustard are Chenopodium album, C. murale, Cyperus rotundas, Cynodon dactylon, Melilotus alba, Asphodelus tenuifolius, Orobanche spp. and Anagallis arvensis.

Farmers have adopted herbicides for weed control because the chemicals can increase the profit, weed control efficiency, production flexibility and reduce time and 
TABLE 10: Influence of irrigation levels and stages on seed yield, oil yield and protein yield of Indian mustard.

\begin{tabular}{lccc}
\hline Treatment & Seed yield $(\mathrm{Kg} / \mathrm{ha})$ & Oil yield $(\mathrm{kg} / \mathrm{ha})$ & Protein yield $(\mathrm{kg} / \mathrm{ha})$ \\
\hline 4 irrigations at $\mathrm{V}+\mathrm{F}+\mathrm{P}+\mathrm{S}$ & 2260 & 909 & 454 \\
3 irrigations at $\mathrm{V}+\mathrm{F}+\mathrm{P}$ & 2250 & 901 & 454 \\
3 irrigations at $\mathrm{V}+\mathrm{F}+\mathrm{S}$ & 2200 & 876 & 442 \\
2 irrigations at V + P & 2150 & 841 & 436 \\
2 irrigations at V + F & 2090 & 803 & 422 \\
2 irrigations at F + P & 2020 & 574 & 417 \\
2 irrigations at P + S & 1520 & 773 & 316 \\
1 irrigation at V & 1920 & 727 & 386 \\
1 irrigation at F & 1790 & 144 & 371 \\
CD at 5\% & 480 & & 94 \\
\hline
\end{tabular}

Note: V: vegetative stage; F: flowering stage; P: pod formation; S: seed development.

Source: AICRP-RM, 1999 [15].

labour requirement for weed management. Hand weeding at 20DAS, fluchloralin preplant incorporation@ $0.75 \mathrm{~kg} / \mathrm{ha}$, wooden hand plough between the lines at 35 DAS on Indian mustard was found effective [51]. Polythene mulch was also found effective in controlling the weeds in mustard [52]. At Bawal, reductions in weed population and dry matter were obtained with fluchloralin supplemented with hand weeding at 30 and 60 DAS, which remained on a par with isoproturon and pendimethalin supplemented with hand weeding at 30 and 60 DAS. Weed-free plot recorded 39.9\% higher seed yield over weedy check [32].

Broomrape (Orobanche) is a major devastating parasitic weed of mustard. Broomrape weed infestation caused $28.2 \%$ average reduction in Indian mustard yield. Among Orobanche spp., O. aegyptiaca is one of the most important parasitic weed causing severe yield and quality reducing factor in rapeseed-mustard. It is endemic in semiarid region and may reach epidemic proportions depending upon soil moisture and temperature. Preceding crop of cowpea, black gram, moth bean, sunn hemp, cluster bean, and sesame significantly reduced Orobanche menace in succeeding mustard crop while sorghum, pearl millet, chilies, and green gram did not influence broomrape infestation in mustard [53]. At Bharatpur, S. K. Nagar and Bawal directed spray of glyphoste (0.25-1.0\%) and 2 drops of soybean oil per young shoot of Orobanche showed effective control and recorded 91.9\% higher seed yield over infected sick plot.

Some cultural practices like mulching and hoeing are also helpful to curb some of the major weeds in mustard by providing a shield against sunlight, reducing the soil temperature and acting as a physical barrier for emergence of weeds. Maximum seed yield $(2540 \mathrm{~kg} / \mathrm{ha}$ ) was obtained in the treatments where plots were kept weed-free followed by the treatment where mulching was done after hoeing (Table 11).

\section{Response to Plant Growth Regulators}

Plant growth regulators (PGR) involved in manipulating plant developments, enhancing yield and quality have been actualized in recent years. Indeterminate plant growth habit, shattering, or dehiscence of fruits and lodging are the
TABLE 11: Seed yield ( $\mathrm{kg} / \mathrm{ha}$ ) and weed population $/ \mathrm{m}^{2}$ as influenced by different weed control practices.

\begin{tabular}{|c|c|c|}
\hline Treatment & Seed yield & $\begin{array}{c}\text { Weed } \\
\text { population } / \mathrm{m}^{2}\end{array}$ \\
\hline Control & 1620 & 57.0 \\
\hline Weed free (Khurpi) & 2520 & 0.0 \\
\hline Hoeing at 25 DAS & 2300 & 19.3 \\
\hline Mulching with bajra florets & 1960 & 23.0 \\
\hline Fluchloralin@ 1 kg a.i./ha PPI & 2000 & 23.0 \\
\hline Pendimethalin@1 kg a.i./ha PE & 2050 & 22.1 \\
\hline Isoproturon@ @ 1 kg a.i./ha PE & 1740 & 26.3 \\
\hline Hoeing at 25 DAS + mulching & 2400 & 17.9 \\
\hline $\begin{array}{l}\text { Fluchloralin@ } 1 \text { kg a.i./ha PPI + } \\
\text { Hoeing }\end{array}$ & 2210 & 20.3 \\
\hline $\begin{array}{l}\text { Fluchloralin @ } 1 \text { kg a.i./ha PPI + } \\
\text { Mulching }\end{array}$ & 2100 & 22.5 \\
\hline $\begin{array}{l}\text { Pendimethalin @ } 1 \mathrm{~kg} \text { a.i./ha PE } \\
\text { + hoeing }\end{array}$ & 2300 & 18.9 \\
\hline $\begin{array}{l}\text { Pendimethalin@1 kg a.i./ha PE } \\
\text { + mulching }\end{array}$ & 1860 & 19.5 \\
\hline $\begin{array}{l}\text { Isoproturon@1 kg a.i./ha PE + } \\
\text { hoeing }\end{array}$ & 1950 & 22.5 \\
\hline $\begin{array}{l}\text { Isoproturon @ } 1 \text { kg a.i./ha PE + } \\
\text { mulching }\end{array}$ & 1910 & 22.9 \\
\hline
\end{tabular}

Source: AICRP-RM, 2002 [21].

most significant and consistent limitations to maximum seed yields in Brassica spp. Considerable seed loss takes place, before or during harvest, due to shattering of fruits, which is correlated with hormonal imbalances and poorly developed lignified cells in the fruit wall. Further, lodging of the crop canopy adversely affects seed quality and yield due to decreased photosynthesis, increased disease severity, impaired rate of drying, and reduced harvest efficiency. Chemical plant growth regulators are being increasingly used as an aid to yield enhancement [54].

Brassinolide is the most bioactive form of the growthpromoting plant steroid termed as Brassinosteroids. Biologically active brassinosteroids show high growth-promoting as well as antistress activity besides other multiple effects on 
TABLE 12: Seed yield (kg/ha) and net returns (Rs./ha) of mustard as influenced by foliar application of agrochemicals at different locations.

\begin{tabular}{|c|c|c|c|c|c|c|}
\hline \multirow{2}{*}{ Treatment } & \multicolumn{2}{|c|}{ S. K. Nagar } & \multirow{2}{*}{$\begin{array}{c}\text { Sriganganagar } \\
\text { Seed yield } \\
(\mathrm{kg} / \mathrm{ha})\end{array}$} & \multicolumn{3}{|c|}{ Ludhiana } \\
\hline & $\begin{array}{l}\text { Seed yield } \\
(\mathrm{kg} / \mathrm{ha})\end{array}$ & $\begin{array}{l}\text { Net returns } \\
\text { over control }\end{array}$ & & Oil content $(\%)$ & Oil yield (kg/ha) & $\begin{array}{c}\text { Glucosinolate }(\mu \text { mole/g } \\
\text { defatted meal })\end{array}$ \\
\hline Control & 1707 & - & 1604 & 34.7 & 375 & 130 \\
\hline Thiourea $(0.1 \%)$ & 2087 & 3226 & 1696 & 35.9 & 429 & 142 \\
\hline S@ @ 40 kg/ha & 2249 & 6712 & 1799 & 35.2 & 405 & 149 \\
\hline $\begin{array}{l}\text { S@ } 90 \mathrm{~kg} / \mathrm{ha}+\text { Thiourea } \\
(0.1 \%)\end{array}$ & 2039 & 4070 & 1883 & 33.4 & 411 & 134 \\
\hline Urea $(2 \%)$ & 2019 & 5409 & 1845 & 34.7 & 396 & 124 \\
\hline $\mathrm{ZnSO}_{4}(0.5 \%)$ & 1921 & 4622 & 1667 & 33.2 & 372 & 126 \\
\hline Boric acid $(0.1 \%)$ & 1928 & 3418 & 1650 & 34.3 & 387 & 115 \\
\hline $\mathrm{CD}$ at $5 \%$ & 150 & 一 & 158 & 一 & 一 & 一 \\
\hline
\end{tabular}

Source: AICRP-RM, 2003 [5].

TABLE 13: Effect of low monetary agrotechniques on seed yield and oil content of mustard at Bharatpur during 1997-1998.

\begin{tabular}{|c|c|c|c|c|}
\hline Treatments & Seed yield (kg/ha) & $\%$ increase over local practice & Oil content $(\%)$ & Oil yield $(\mathrm{kg} / \mathrm{ha})$ \\
\hline Local Practice (T1) & 1200 & - & 40.3 & 463 \\
\hline RP (No thinning and gypsum) (T2) & 1371 & 14.2 & 40.3 & 525 \\
\hline $\mathrm{RP}+$ thinning at $15 \& 25 \mathrm{DAS}(\mathrm{T} 3)$ & 1407 & 17.3 & 40.5 & 560 \\
\hline $\mathrm{T}_{3}+\mathrm{N}-\mathrm{S}$ sowing $(\mathrm{T} 4)$ & 1376 & 14.7 & 40.7 & 560 \\
\hline $\mathrm{T}_{3}+$ Removal of 4 th row and 4 th plant (T5) & 1156 & 3.7 & 40.4 & 467 \\
\hline $\mathrm{T}_{5}+56.75 \% \mathrm{~N}$ as top dressing $(\mathrm{T} 6)$ & 1073 & 10.6 & 40.3 & 432 \\
\hline $\mathrm{T}_{3}+\mathrm{I}$ irrigation at $40-50 \mathrm{DAS}(\mathrm{T} 7)$ & 1232 & 2.7 & 40.6 & 500 \\
\hline $\mathrm{T}_{1}+200 \mathrm{~kg}$ gypsum/ha $(\mathrm{T} 8)$ & 1217 & 1.4 & 40.9 & 500 \\
\hline $\mathrm{T}_{3}+$ removal of 4 older leaves $(\mathrm{T} 9)$ & 1343 & 11.9 & 40.5 & 544 \\
\hline $\mathrm{RP}+$ de-topping at bud-initiation stage $(\mathrm{T} 10)$ & 1464 & 22 & 40.7 & 596 \\
\hline
\end{tabular}

Source: AICRP-RM, 1998 [12].

growth and development. As botanical juvenile hormones, they enhance the growth of young plant tissue and stimulate in submicromolar concentrations metabolic, differentiation and growth processes. Brassinosteroid caused accumulation of maximum total dry matter as compared to rest of the treatment at physiological maturity.

NPK accumulation and yield were maximal when spraying of $\mathrm{GA}_{3}$ was done at 40 DAS [55]. An increase in secondary and tertiary branching with consequent enhancement in seed yield through increased number of infloresence and siliquae per plant was observed with the application of Mixatalol (a mixture of long aliphatic alcohols varying in chain length from $\mathrm{C}_{24}$ to $\mathrm{C}_{32}$ ) to Brassica plants as foliar spray [56]. The percentage of immature siliquae and shattering of siliquae decreased with this treatment. Mixtalol increased total dry matter of plants, partitioning coefficient, and harvest index. The contents of starch, protein, and oil were also higher in seeds from mixtalol treated plants.

The maximum plant height $(169.1 \mathrm{~cm})$, number of primary branches per plant (8.2), seed yield (2031 kg/ha), stover yield $(5752 \mathrm{~kg} / \mathrm{ha})$, harvest index $(26.1 \%)$, oil content $(42 \%)$, and net returns (Rs. 20,471/ha) were recorded with thiourea (Shrama and Jain, 2003). At Bawal and Morena, highest seed yield $(2060 \mathrm{~kg} / \mathrm{ha})$ was obtained with $40 \mathrm{kgS} / \mathrm{ha}+$ thiourea $(0.1 \%)$. At Sriganganagar, significantly higher seed yield $(1883 \mathrm{~kg} / \mathrm{ha})$ was recorded on a par with $40 \mathrm{~kg} \mathrm{~S} / \mathrm{ha}+$ thiourea $(0.05 \%)$, urea $(2 \%), \mathrm{H}_{2} \mathrm{SO}_{4}(0.1 \%)$, and $40 \mathrm{~kg} \mathrm{~S} / \mathrm{ha}$. $40 \mathrm{~kg} \mathrm{~S} / \mathrm{ha}+$ thiourea $(0.1 \%)$ resulted into $17.67 \%$ higher seed yield over no spray. The highest oil content (35.9\%) was recorded with thiourea $0.1 \%$ spray. Glucosinolate content ranged from 115 to 154 ( $\mu$ mole/g defatted meal) in different treatment (Table 12).

\section{Impact of Low Monetary Agrotechniques on Mustard Productivity}

Agricultural inputs like fertilizer, irrigation, insecticides, pesticides, and herbicides, and so forth, are very expensive. Some nonmonetary or low monetary inputs can enhance the yield considerably with a slight increase in the cost of cultivation. There are a number of low monetary agro techniques which enhance the mustard yield considerably (Table 13). For harvesting the maximum yield of rapeseed-mustard at a given situation, all the production technologies, like, soil amendments, thinning, nutrient supply, sowing direction, irrigation, plant protection, and so forth should be planned well in advance. At Bharatpur, highest seed yield (1464 kg/ha) was recorded with the application of recommended practice (RP) + thinning at 15 and 25 DAS + detopping 
at bud-initiation stage followed by RP + thinning at 15 and 25 DAS.

\section{Future Line of Research}

Rapeseed-mustard will continue to contribute considerably to the oilseed bowl of the country. A streamlined research programme for rapeseed-mustard should be focused on the below-mentioned points.

(i) Horizontal and vertical intensification in rapeseedmustard production needs to be done for selfsufficiency in oilseed production. It is possible through varietal improvement and introduction of mustard in nontraditional areas.

(ii) An optimum agronomic package of practices for high yielding and insect, pest, and disease resistant varieties, along with the upcoming hybrids needs to be worked out.

(iii) Adoption of site-specific nutrient management (SSNM), precision agriculture, and conservation agriculture can bring more profits to the mustard growers.

(iv) An integrated weed management approach needs to be developed for problematic and parasitic weeds in mustard. Orobanche is becoming a serious constraint and for its management a holistic approach which includes GM techniques needs to be explored.

(v) Suitable crop models and simulation for various inputs like water and nutrients will be helpful to target the most productive and most potential mustard growing zones of India.

\section{Conclusion}

The tremendous increase in oilseed production is attributed to the development of high yielding varieties coupled with improved production technology, their widespread adoption and good support price. To meet the ever-growing demand of oil in the country, the gap is to be bridged through management techniques. The vertical growth in mustard production can be brought by exploiting the available genetic resources with breeding and biotechnological tools which will break the yield barriers. Horizontal growth in rapeseed-mustard can be brought in those rapeseed-mustard growing areas/districts of the country, wherever, the yield is lower than the national average. Production technologies for different agroecological cropping systems, crop growing situations like intercropping, salinity, rainfall, and so forth, under unutilized farm situations like rice-fallows, mustard to be followed after cotton, sugarcane, soyabean, and so forth, and mustard as a paira crop in rice with lathyrus, lentil or any other competing rabi crop in traditional and nontraditional areas, need to be worked out. It is estimated that at least 1 million hectares can be brought under cultivation, through adoption of such cropping systems.

Proper land preparation, proper time of sowing, selection of better quality seeds, and so forth are always neglected.
Fertilizer application is little or nonexistent leading to poor productivity. Whether little is spent on fertilizer input goes entirely on nitrogenous fertilizers. This results in a big gap between requirement and production of mustard in India. Therefore site-specific nutrient management through soil-test recommendation based should be adopted to improve upon the existing yield levels obtained at farmers field. Optimum crop geometry, balanced NPK fertilizers, intercultural operations, and inclusion of farmyard manure are the building blocks for achieving the utmost yield targets of rapeseed-mustard. Effective management of natural resources, integrated approach to plant-water, nutrient and pest management and extension of rapeseed-mustard cultivation to newer areas under different cropping systems will play a key role in further increasing and stabilizing the productivity and production of rapeseed-mustard to realize 24 million tonnes of oilseed by 2020 AD.

\section{References}

[1] India. Directorate of Economics and Statistics, Agricultural Statistics at a Glance, Department of Agricultural and cooperation. Ministary of Agriculture, Government of India, 2010.

[2] J. S. Chauhan, K. H. Singh, and A. Kumar, "Compendium of Rapeseed-mustard varieties notified in India," Directorate of Rapeseed-Mustard Research, Bharatpur, Rajasthan, pp. 7-13, 2006.

[3] M. A. Asoodari, A. R. Barzegar, and A. R. Eftekhar, "Effect of different tillage and rotation on crop performance," International Journal of Agrcultural Biology, vol. 3, no. 4, article 476, 2001.

[4] A. L. Rathore, A. R. Pal, and K. K. Sahu, "Tillage and mulching effects on water use, root growth and yield of rainfed mustard and chickpea grown after lowland rice," Journal of Science of Food and Agriculture, vol. 78, no. 2, pp. 149-161, 1999.

[5] AICRP-RM, Annual Progress Report of National Research Centre on Rapeseed-mustard.2002-2003, pp. 11-14, 2003.

[6] T. Nagra, R. E. Phillip, and J. E. Legett, "Diffusion and mass flow of nitrate-N into corn roots under field conditions," Agronomy Journal, vol. 68, pp. 67-72, 1976.

[7] R. L. Blevins, M. S. Smith, and G. W. Thomas, "Change in soil properties under no tillage," in No Tillage Agriculture, pp. 190230, New York, NY, USA, 1984.

[8] S. Snapp, R. Price, and M. Morton, "Seed priming of winter annual cover crops improves germination and emergence," Agronomy Journal, vol. 100, no. 5, pp. 1506-1510, 2008.

[9] N. A. Khan and S.O. Aziz, "Response of mustard to seed treatment with pyridioxine and basal and foliar application of nitrogen and phosphorus," Journal of Plant Nutrition, vol. 16, no. 9, pp. 1651-1659, 1993.

[10] A. Kumar, B. Singh, Yashpal, and J. S. Yadava, "Effect of sowing time and crop geometry on tetralocular Indian mustard," Indian Journal of Agricultural Sciences, vol. 62, no. 4, pp. 258262, 2001.

[11] AICRP-RM, Annual Progress Report of All India Coordinated Research Project on Rapeseed-Mustard, pp. 97-147, 1997.

[12] AICRP-RM, Annual Progress Report of National Research Centre on Rapeseed-mustard. 1997-98, pp. 8-18, 1998.

[13] R. Gupta, R. P. Avasthi, and S.J. Kolte, "Influence of sowing dates on the incidence of Sclerotinia stem rot of Rapeseedmustard," Annals of Plant Protection Sciences, vol. 12, no. 1, pp. 223-224, 2004. 
[14] AICRP-RM, Annual Progress Report of All India Coordinated Research Project on Rapeseed-Mustard, pp. A1-16, 2007.

[15] AICRP-RM, Annual Progress Report of All India Coordinated Research Project on Rapeseed-Mustard, pp. A1-44, 1999.

[16] G. M. Khan and S. K. Agarwal, "Influence of sowing methods, moisture Stress and nitrogen levels on growth, yield components and seed yield of mustard," Indian Journal of Agricultural Science, vol. 55, no. 5, pp. 324-327, 1985.

[17] M. J. Khan, R. A. Khattak, and M. A. Khan, "Influence of sowing methods on the production of canola grown in saline field," Pakistan Journal of Biological Sciences, vol. 3, no. 4, pp. 687-691, 2000.

[18] F. C. Oad, B. K. Solangi, M. A. Samo, A. A. Lakho, HassanUl-Zia, and N. L. Oad, "Growth, yield and relationship of Rapeseed (Brassica napus L.) under different row spacing," International Journal of Agriculture and Biology, vol. 3, no. 4, pp. 475-476, 2001.

[19] H. P. Sierts and G. Geister, "Yield components stability in winter rape (Brassica napus L.) as a function of competition within the crop," in Proceedings of the 7th International Rapeseed Congress, p. 182, Poznan, Poland, May 1987.

[20] AICRP-RM, Annual Progress Report of All India Coordinated Research Project on Rapeseed-Mustard, pp. 97-144, 1996.

[21] AICRP-RM, Annual Progress Report of National Research Centre on Rapeseed-mustard. 2001-02, pp. 29-34, 2002.

[22] K. K. Singh and K. S. Rathi, "Dry matter production and productivity as influenced by staggered sowing of mustard intercropped at different row ratios with chickpea," Journal of Agronomy and Crop Science, vol. 189, no. 3, pp. 169-175, 2003.

[23] S. Chitale and M. C. Bhambri, "Response of Rapeseedmustard to crop geometry, nutrient supply, farmyard manure and interculture-a review," Ecology, Environment and Conservation, vol. 7, no. 4, pp. 387-396, 2001.

[24] R. Sharma, K. S. Thakur, and P. Chopra, "Response of N and spacing on production of Ethopian mustard under mid-hill conditions of Himachal Pradesh," Research on Crops, vol. 8, no. 1, pp. 65-68, 2007.

[25] D. Sah, J. S. Bohra, and D. N. Shukla, "Effect of N, P, S on growth attributes and nutrient uptake of mustard," Crop Research, vol. 31, no. 1, pp. 234-236, 2006.

[26] M. L. Reager, S. K. Sharma, and R. S. Yadav, "Yield attributes, yield and nutrient uptake of Indian mustard (Brassica juncea) as influenced by $\mathrm{N}$ levels and its split application in arid Western Rajasthan," Indian Journal of Agronomy, vol. 51, no. 3, pp. 213-216, 2006.

[27] A. S. Sidhu and K. S. Sandhu, "Response of mustard to method of $\mathrm{N}$ application and timing of first irrigation," Journal of Indian Society of Soil Science, vol. 43, no. 3, pp. 331-334, 1995.

[28] H. L. S. Tandon, S Research and Agricultural Production in India, Fertilizer Development and Consultation Organization, New Delhi, India, 2nd edition, 1986.

[29] M. R. J. Holmes, Nutrition of the Oilseed Rape Crops, Applied science publishers, Essex, UK, 1980, In TSI/FAI/IFA Symposium.

[30] M. S. Aulakh and N. S. Pasricha, "S fertilization of oilseeds for yield and quality," in Proceedings of the TSI-FAI symposium. S in agriculture-S-11/3, 1988.

[31] J. C. Katyal, K. L. Sharma, and K. Srinivas, S in Indian agriculture. pp. KS-2/1-2/12, 1997.

[32] AICRP-RM, Annual Progress Report of All India Coordinated Research Project on Rapeseed-Mustard, pp. A1-22, 2007.

[33] AICRP-RM, Annual Progress Report of National Research Centre on Rapeseed-mustard. 1999-2000, pp. 24, 2000.
[34] M. Gupta and R. D. Kaushik, "Effect of saline irrigation water and $\mathrm{Zn}$ on the concentration and uptake of $\mathrm{Zn}$ by mustard," in Proceedings of the 18th World Congress of Soil science, Philadelphia, Pa, USA, July 2006.

[35] AICRP-RM, Annual Progress Report of All India Coordinated Research Project on Rapeseed-Mustard, pp. A1-28, 2005.

[36] AICRP-RM, Annual Progress Report of National Research Centre on Rapeseed-mustard. 2004-05, pp. 9-11, 2005.

[37] R. Prasad, S. N. Sharma, S. Singh, and R. Lakshaman, "Agronomic practices for increasing nutrient use efficiency and sustained crop production," in Proceedings of the National Seminar on Resource Management for Sustainable Production, New Delhi, India, February 1992.

[38] M. A. Bhat, Singh, Room, and D. Dash, "Effect of INM on uptake and use efficiency of $\mathrm{N}$ and $\mathrm{S}$ in Indian mustard on an inceptisol," Crop Research, vol. 30, pp. 23-25, 2005.

[39] B. S. Kumpawat, "Integrated nutrient management for maizemustard cropping system," Indian Journal of Agronomy, vol. 49, pp. 4-7, 2004.

[40] K. M. Hati, A. K. Mishra, K. G. Mandal, P. K. Ghosh, and K. K. Bandopadhyay, "Irrigation and nutrient management effect on soil physical properties under soybean-mustard cropping system," Agricultural Water Management, vol. 85, no. 3, pp. 279-286, 2006.

[41] N. Pandey, R. S. Tripathi, and B. N. Mittra, "N, P and water management in greengram-rice-mustard cropping system," Annals of Agricultural Reseaarch, vol. 25, no. 2, pp. 298-302, 2004.

[42] S. S. Parihar, "Influence of $\mathrm{N}$ and irrigation schedule on yield, water use and economics of summer rice," International Journal of Tropical Agriculture, vol. 19, no. 1-4, pp. 157-162, 2001.

[43] R. K. Ghosh, P. Bandopadhyay, and N. Mukhopadhyay, "Performance of Rapeseed-mustard cultivars under various moisture regimes on the Gangetic Alluvial Plain of West Bengal," Journal of Agronomy and Crop Sciences, vol. 173, no. 1, pp. 5-10, 1994.

[44] S. K. Yadav, K. Chander, and D. P. Singh, "Response of latesown mustard to irrigation and N," The Journal of Agricultural Sciences, vol. 123, pp. 219-224, 1994.

[45] B. B. Panda, S. K. Bandyopadhyay, and Y. S. Shivay, "Effect of irrigation level, sowing dates and varieties on yield attributes, yield, consumptive water use and water-use efficiency of Indian mustard," Indian Journal of Agricultural Sciences, vol. 74, no. 6, pp. 339-342, 2004.

[46] I. Piri, "Effect of irrigation on yield, quality and wateruse-efficiency of Indian mustard," in Proceedings of the 14th Australian Society of Agronomy Conference, Adelaide, Australia, September 2008.

[47] Gangasaran and G. Giri, "Growth and yield of mustard as influenced by irrigation and plant population," Annals of Agricultural Research, vol. 7, no. 1, pp. 68-74, 1986.

[48] C. P. S. Chauhan and R. B. Singh, "Mustard performs well even with saline irrigation," Indian Farming, vol. 42, pp. 1720, 2004.

[49] M. A. Kahlown, M. Akram, Z. A. Soomro, and W. D. Kemper, "Prospectus of growing barley and mustard with saline ground water irrigation in fine and coarse textured soils of Cholistan desert," Irrigation and Drainage, vol. 51, no. 4, pp. 328-338, 2008.

[50] D. K. Majumdar, "Effect of supplementary saline irrigation and applied $\mathrm{N}$ on the performance of dryland seeded Indian 
mustard," Experimental Agriculture, vol. 31, pp. 423-428, 1995.

[51] J. Pandey and B. N. Mishra, "Effect of weed management practices in a rice-mustard-mungbean cropping system on weeds and yield of crops," Annals of Agricultural Reaseach, vol. 24, no. 4, pp. 36-39, 2003.

[52] B. R. Bazaya, D. Kachroo, and R. K. Jat, "Integrated weed management in mustard (Brassica juncea)," Indian Jounal of Weed Science, vol. 38, no. 1-2, pp. 16-19, 2006.

[53] S. Kumar, "Identification of trap crop for reducing broomrape infestation in the succeeding mustard," Agronomy Digest, vol. 2, pp. 99-101, 2002.

[54] M. Mobin, H. R. Ansari, and N. A. Khan, "Timing of GA3 application to indian mustard: DM distribution, growth analysis and nutrient uptake," Journal of Agronomy, vol. 6, no. 1, pp. 53-60, 2007.

[55] N. A. Khan, H. R. Ansari, and Samiullah, "Effect of gibberellic acid spray during ontogeny of mustard on growth, nutrient uptake and yield characteristics," Journal of Agronomy and Crop Science, vol. 181, no. 1, pp. 61-63, 1998.

[56] R. C. Setia, Richa, N. Setia, K. L. Ahuja, and C. P. Malik, "Effect of Mixtalol on growth, yield and yield components of Indian mustard (Brassica juncea)," Plant Growth Regulation, vol. 8, no. 2, pp. 185-192, 1989. 


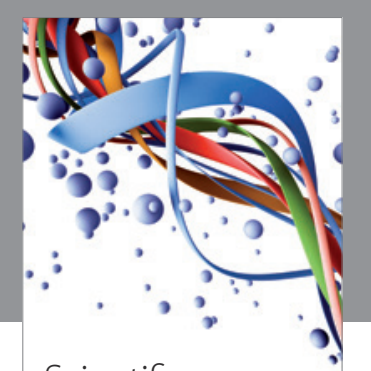

Scientifica
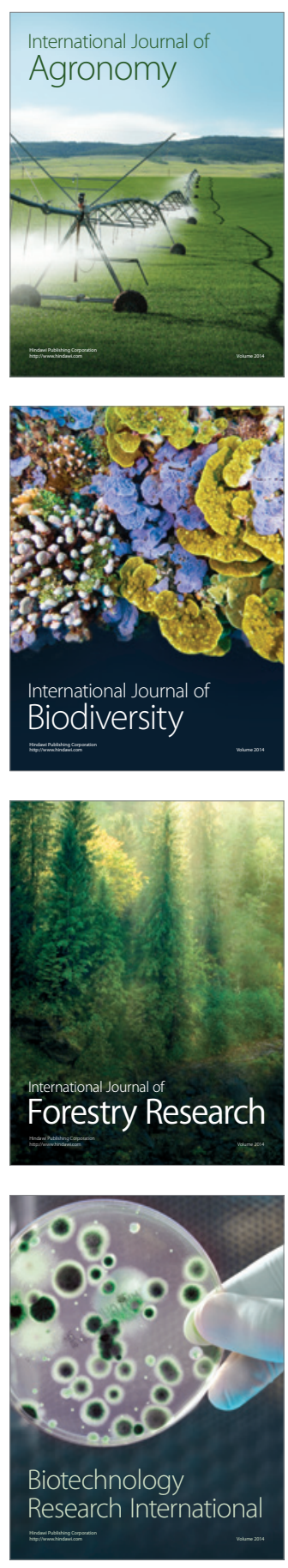
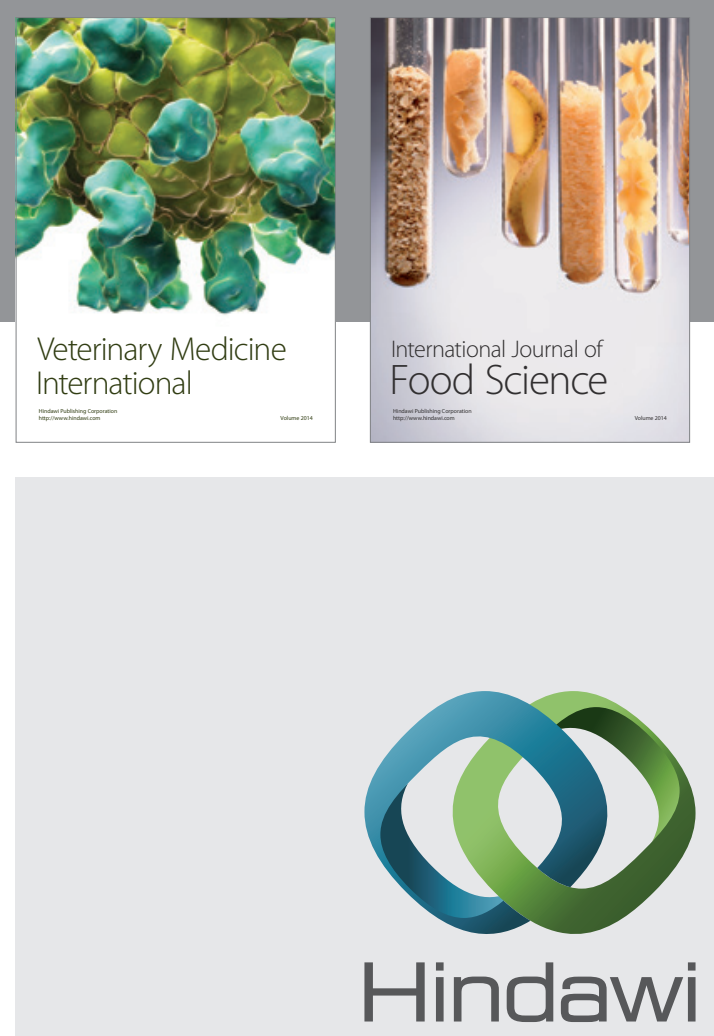

Submit your manuscripts at

http://www.hindawi.com
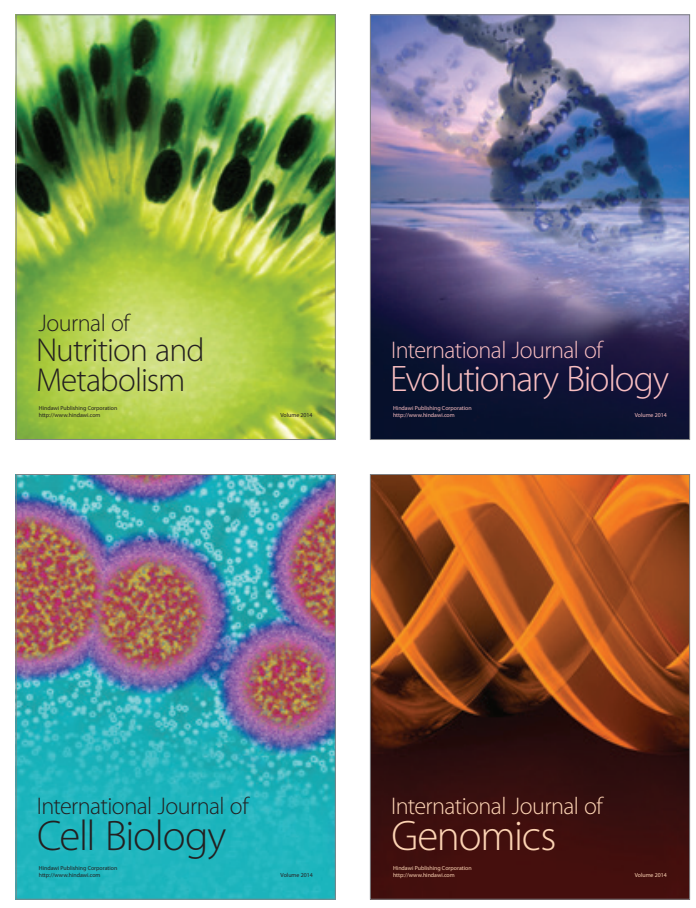
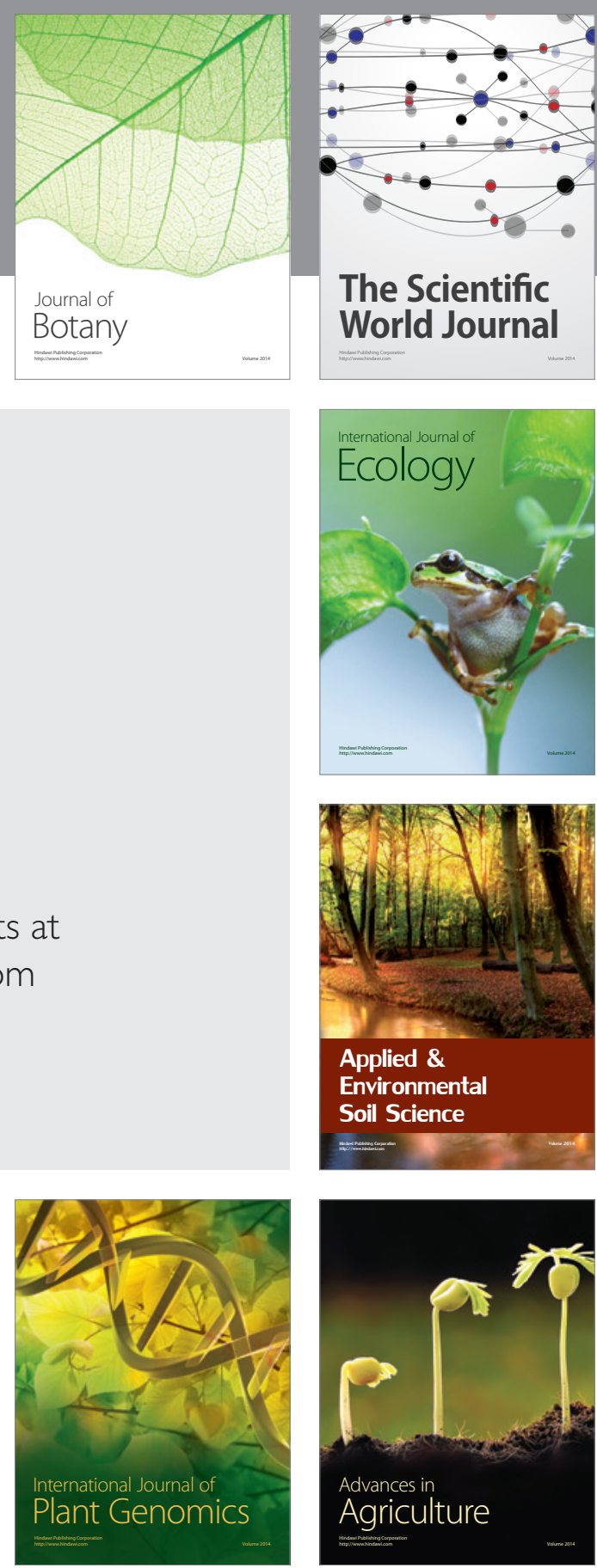

The Scientific World Journal
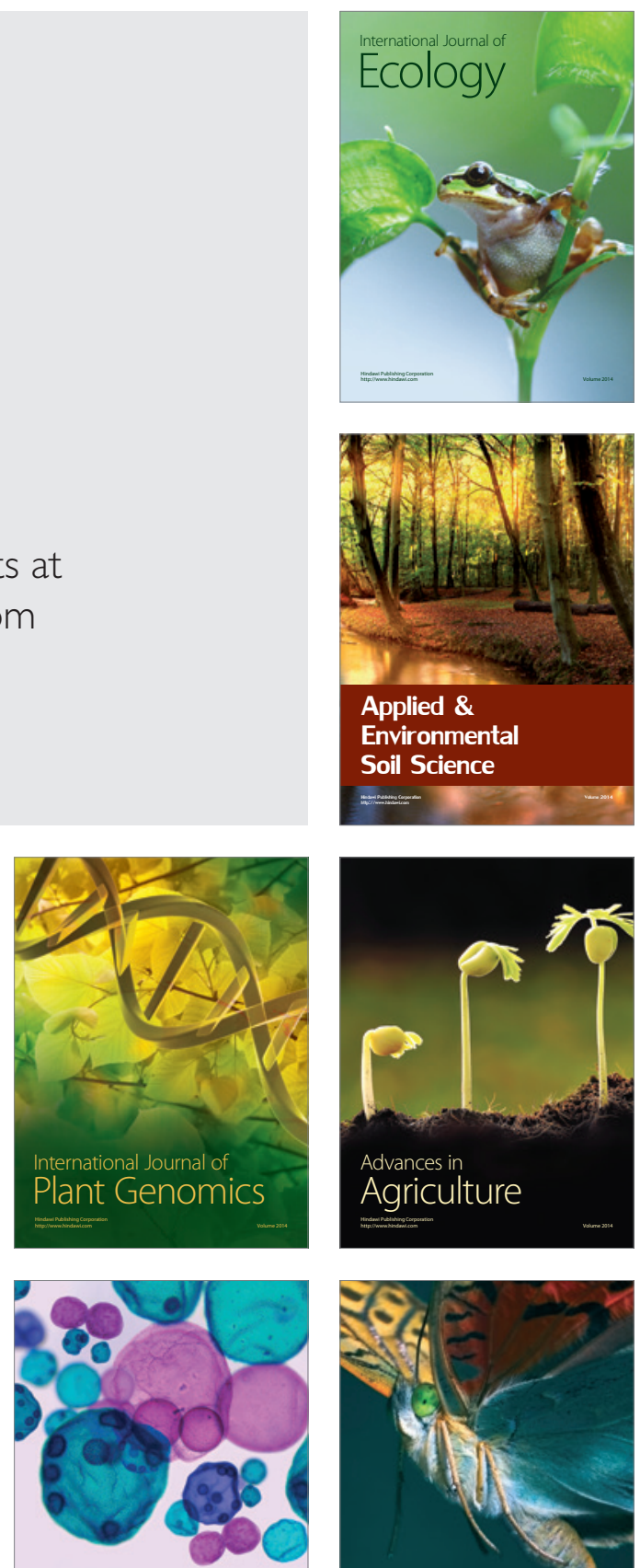

International Journal of Microbiology

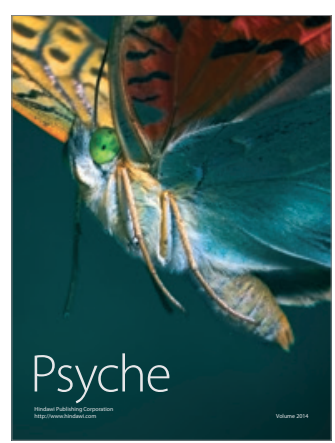

